\section{NOTES ON THE DISTRIBUTION AND ETHNOBOTANY OF SOME MEDICINAL ORCHIDS IN NILGIRI BIOSPHERE RESERVE}

\section{P. Balasubramanian, A. Rajasekaran and S. Narendra Prasad}

Salim Ali Centre for Ornithology and Natural History, Anaikatty, Coimbatore, Tamil Nadu 641108, India.

During ethnobotanical surveys in the Nilgiri Biosphere Reserve, Western Ghats, we encountered several orchid species. Of those, the following four species were found interesting because of their ethnobotanical importance. These plant species are used for medicinal purposes by tribals inhabiting forest settlements. Their ethnomedicinal uses along with notes on distribution within Nilgiri Biosphere Reserve are given below.

Cymbidium aloifolium (L.) Sw.

Sikadolai

Habit and Distribution: An epiphytic orchid, commonly noticed on trees such as Hardwickia binata and Drypetes sepiaria. Recorded in the dry mixed deciduous forests of Coimbatore and dry deciduous forests in Sathyamangalam division.

Ethnobotany: Used by the Kurumbas. Leaves are heated slightly and the juice is dropped in the ear for the treatment of otitis and other inflammatory conditions. Emetic and purgative; salep used as a nutrient and demulcent (Yoganarasimhan, 1996). Whole plant collected on large scale for commercial use, probably used by the Siddha and Ayurveda pharmaceutical industries.

Nervilia aragoana Gaudich.

Orilaithamarai

Habit and Distribution: A small terrestrial orchid with globose white tubers. Leaves appear after flowering. Commonly recorded in the moist deciduous and moist localities of dry deciduous forests of Mudumalai and Wynad Wildlife Sanctuaries and Bandipur National Park.

Ethnobotany: Use not recorded in present study. However, earlier studies indicate that the whole plant is used in the preparation of ayurvedic drugs (Sivarajan \& Balachandran, 1994) and collected on large scale in Kerala (Sasidharan, 1991). The decoction of leaves is used as a protective medicine after childbirth in Malaysia (Anon, 1966; Yoganarasimhan, 1996).

Vanda tessellata (Roxb.) Hook.f. ex Don Sekuttu Vazhai Habit and Distribution: An epiphytic orchid with large showy

Received on 25 April 2000 Accepted on 1 September 2000 flowers. Commonly noticed in the dry deciduous and mixed dry deciduous forests of Coimbatore, Sathyamangalam divisions, Attappady Reserve Forest and Mudumalai Wildlife Sanctuary.

Ethnobotany: Used by Irulas. Leaves are heated slightly and the juice is dropped in the ear for the treatment of otitis and other inflammatory conditions. Roots are used in dyspepsia, bronchitis, rheumatism and fevers. Roots form a constituentof medicated oils used externally on rheumatic swellings and nervous troubles (Yoganarasimhan, 1996). Root is antipyretic, laxative, tonic to the liver and brain; used in rheumatism, secondary syphilis, dyspepsia, bronchitis, inflammations, hiccups, tremors, piles, lumbago, toothache, boils on scalp, heals fractures, diseases of the nervous system and abdomen; leaf used externally in fever (Husain, 1992). The anti-inflammatory activity of this species has been proved (Anon, 1976).

Vanilla walkeriae Wight

Kundu Pirandai

Habit and Distribution: A straggling root climber on large shrubs or trees. Stem stout, dark green with aerial roots at the nodes. Rudimentary leaves found at the growing tips. Commonly noticed in dry mixed deciduous forests of Coimbatore division.

Ethnobotany: Very widely used in ethnobotany medicine by Irulas. Stem paste is orally administrated along with feed to treat fever in cattle. Stem paste is also used as a nutritive supplement for cattle.

The commercial exploitation of these species coupled with habitat destruction is likely to reduce their population. Hence, adequate management actions including both in situ and ex situ conservation measures need to be undertaken.

\section{Acknowledgements}

We are thankful to the Ministry of Environment and Forests, Government of India for sponsoring the ethnoecology project; Forest Departments of Tamil Nadu and Kerala for giving permission for field work; BSI, Southern Circle for permitting us to use the herbarium facilities.

\section{References}

Anon (1966). The Wealth of India - Raw Materials. Council of Scientific and Industrial Research, New Delhi 18 pp.

Anon (1976). The Wealth of India - Raw Materials. Council of Scientific and Industrial Research, New Delhi 432 pp.

Husain, A. (1992). Dictionary of Indian Medicinal Plants. Central Institute of Medicinal and Aromatic Plants, Lucknow, p. 483.

Sasidharan, N. (1991). Conservation of rare and threatened medicinal plants in the forest of Kerala. In: Karunakaran, C.K. (ed.). Proceedings of the Symposium on Rare Endangered and Endemic Plants of the Western Ghats, Kerala Forest Department (Wildlife Wing), Thiruvananthapuram, Kerala, pp. 227-229.

Sivarajan V.V. and I. Balachandran, (1994). Ayurvedic drugs and their plant sources. Oxford \& IBH Publishing Co. Ltd., pp. 335-337. Yoganarasimhan, S.N. (1996). Medicinal Plants of India, Vol. I Karnataka. Interline Publishing Private Limited, Bangalore pp. 155, 330, 493. 